\title{
Sastra Lisan Nandung di Riau
}

\author{
Rofiandri Suardi ${ }^{1}$ dan Sunarto \\ Prodi Pendidikan Seni, Pascasarjana Universitas Negeri Semarang
}

\begin{abstract}
Oral Literature of Nandung in Riau. This research aims to identify the form of Nandung oral literary performance and the values found in it. Nandung is an oral literature used to put children to bed, which isdelivered by poems in the form of pantun, and hummed rhythmically (humming). Today, Nandung has evolved into a form of performing arts. The data were obtained from the observation of oral literature in Rengat city, Indragiri Hulu of Riau. Based on the research result it can be concluded that there are 7 sub forms of performances in oralliterature of nandung, namely the speakers, the musical accompaniment, the stage, the costume, the audiences, the poetry, and the language used. While the values found in the poetry are the religious, moral, and educational values.
\end{abstract}

Keywords: Nandung; Riau oral poetry; Indragiri

\begin{abstract}
ABSTRAK
Penelitian ini bertujuan untuk mengidentifikasi bentuk pertunjukan sastra lisan Nandung dan nilainilai yang terkandung di dalamnya. Nandung adalah sastra lisan yang digunakan untuk menidurkan anak, disampaikan dengan syair yang berbentuk pantun, dan dilantunkan dengan berirama atau bersenandung. Saat ini, Nandung telah berkembang menjadi sebuah seni pertunjukan. Data diperoleh dari pengamatan terhadap kesenian sastra lisan Nandung di Kota Rengat, Indragiri Hulu, Riau. Berdasarkan penelitian disimpulkan bahwa terdapat 7 sub bentuk pertunjukan dalam sastra lisan Nandung, yaitu penutur, musik pengiring, panggung, kostum, penonton, syair, serta bahasa yang digunakan. Sedangkan nilai yang terdapat dalam syairnya yaitu nilai religius, moral, dan pendidikan.
\end{abstract}

Kata kunci: Nandung; sastra lisan Riau; Indragiri

\section{Pendahuluan}

Kota Rengat adalah salah satu kota yang berada di Kabupaten Indragiri Hulu Provinsi Riau. Pada zaman dahulu, di kabupaten ini berdiri sebuah kerajaan yang bernama Kerajaan Indragiri, yang mana replika bangunan kerajaan masih berdiri di sekitar kawasan wisata Danau Raja, yang terletak di tengah Kota Rengat. Keberadaan bekas kerajaan ini juga bisa dibuktikan dengan adanya kompleks pemakaman para raja yang pernah memerintah di Kerajaan Indragiri ini. Salah satu makam yang ada di komplek ini adalah makam Raja Narasinga II.

Penduduk kota Rengat mayoritas terdiri dari suku Melayu, akan tetapi selain suku Melayu, terdapat juga suku-suku lainnya yang berada di Kota Rengat dan Kabupaten Indragiri Hulu ini, yaitu suku Minang, Batak, Jawa, Tionghoa, Banjar, Sunda, dan juga suku pedalaman seperti Sakai dan Talang Mamak. Dengan beragamnya suku yang ada, terdapat juga beragam kebudayaan dan kesenian yang berkembang di Kota Rengat.

Masyarakat Kota Rengat memiliki beragam macam jenis kesenian, seperti Surat Kapal, Berdah, Berzanji, Begambus, Dabus, Besilat, Begawai, Tari Rentak Bulian dan Nandung. Dari beragam kesenian yang ada, nandung merupakan salah satu kesenian yang masih dilestarikan di Kabupaten Indragiri Hulu khususnya di daerah seberang Kota Rengat, seperti Kampung Pulau, Kampung Besar Seberang, dan Rantau Mapesai.

$1 \quad$ Alamat korespondensi: Prodi Pendidikan Seni, Pascasarjana Universitas Negeri Semarang, Jln. Kelud Utara III, Petompon, Gajah Mungkur, Semarang. E-Mail: acordioner@ymail.com; HP: +6285272007541 
Nandung adalah sastra lisan yang digunakan untuk menidurkan anak yang disampaikan dengan syair yang berbentuk pantun dan dilantunkan dengan berirama atau bersenandung. Syair dalam nandungseperti pantun yang memiliki sampiran dan isi, serta dengan bentuk pola $a b$ dan $a b$. Nandung juga memiliki arti yang sama dengan kata nyanyian, yaitu melantunkan lirik-lirik (pantun) dengan cara dinyanyikan dengan menggunakan irama yang khas untuk menidurkan anak. Nandung berisikan syair tentang agama, nasehat, akhlak, tunjuk ajar, dan pengajaran pendidikan. Nandung sendiri merupakan bagian dari tradisi lisan. Penggunaan tradisi lisan dalam kehidupan sehari-hari melalui berbagai bentuk dapat bersifat intens dan tidak intens (Syarifuddin, 2009: 81; Sibarani, 2015: 94-95)

Ahmad Darmawi (2006) mengungkapkan bahwa istilah Nandung yang dimaksud dalam hubungannya dengan salah satu genre sastra lisan masyarakat Indragiri Hulu dapat didefinisikan sebagai berikut: rangkaian kata berbentuk pantun yang dinyanyikan dengan irama untuk mendodoi atau menidurkan anak di kalangan masyarakat tempatan dan atau yang berasal dari Indragiri Hulu (2006:17).

Maizar Karim (2015) mengungkapkan bahwa Melayu sebagai salah satu kelompok etnis di Nusantara (Indonesia) memiliki khazanah sastra yang banyak, baik yang berbentuk tertulis (naskah) maupun tidak tertulis (lisan). Dalam hal ini, sastra lisan Nandung termasuk dalam salah satu khazanah sastra melayu yang ada di Indonesia, khususnya melayu Provinsi Riau.

Penanaman akhlak yang baik sudah seharusnya diterapkan kepada anak-anak sejak dini. Dalam kesenian nandung di Kota Rengat Kabupaten Indragiri Hulu, nilai-nilai yang berisikan tentang akhlak mulia, petuah agama, dan nasehat telah disampaikan kepada anak-anak sejak dari buaian (sejak kecil). Penanaman nilai Islami sudah terlihat dari awal penuturan syair nandung ini, yaitu dibacakannya kalimat La Ilaha Illallah, Muhammad Rasulullah. Hal ini senantiasa disampaikan untuk selalu mengingat Allah SWT dan Nabi Muhammad SAW.

Rahman, dkk (2010: 14) mengungkapkan unsur seni dapat ditemukan yang berhubungan dengan sistem kepercayaan, setiap seni merupakan gagasan yang bersumbu dari keyakinan. Seni-seni Melayu adalah seni yang terikat pada kepercayaan ketuhanan, dan untuk sebagian besar wujud dari seni itu sekaligus untuk memperkuat kepercayaan itu. Seperti halnya Nandung, sastra lisan ini erat kaitannya dengan pengajaran agama Islam.

Masyarakat melayu di Kota Rengat dan sekitarnya sangat mengutamakan unsur-unsur pendidikan Islami dalam syair Nandung ini, setiap kalimat yang disampaikan mengandung arti yang sesuai dengan ajaran agama Islam, seperti beriman kepada Allah SWT dan Rasul-Nya, percaya kepada takdir, menjauhi sifat-sifat yang buruk, menghormati orang tua, serta melakukan kebaikan. Kesenian Nandung ini juga merupakan seni yang beranjak dari keluhuran budi yang harus ditanamkan ke dalam diri dan jiwa anak-anak sedari dini, tidak lupa dilantunkan kalimat $L a$ Ilaha Illallah, Muhammad Rasulullah untuk selalu mengajarkan anak-anak bahwa agama merupakan pedoman hidup yang harus dipegang teguh dalam menjalani kehidupan sehari-hari.

Mailiswin (wawancara, Februari 2017) mengungkapkan masuknya kesenian Nandung ini tidak diketahui pasti kapan dan asal muasalnya karena pada zaman dulu, ibu-ibu sudah terbiasa menandungkan anaknya ketika di dalam buaian. Ketika bapak-bapak sedang mencari nafkah seperti berkebun, mencari ikan di sungai, dan berdagang di pasar, ibu-ibu di rumah akan menandungkan anaknya menjelang tidur, dan ketika anak sudah tidur, maka ibu bisa menjalankan aktivitas di rumah. Dilihat dari perkembangannya, saat ini kesenian Nandung mulai ramai diperlombakan dan dipertunjukan dalam acara-acara besar daerah Kota Rengat Kabupaten Indragiri Hulu.

Pada dasarnya, aktivitas dari kesenian sastra lisan Nandung ini hanya terdapat di dalam ruang lingkup keluarga. Akan tetapi, perkembangannya saat ini mulai ditampilkan saat acara-acara peringatan hari besar di Kabupaten Indragiri Hulu. Perubahan ini tentunya merupakan upaya pelestarian dari pihak-pihak yang bertanggung jawab dalam mempertahankan eksistensi suatu karya seni yang menjadi identitas dari daerah itu sendiri. Budaya lisan itu cenderung sebagai budaya kolektif se- 
hingga identitas individu-individu itu hadir sebagai bagian dari budaya kolektif (Rhoads, 2010: 158).

Terdapat dua jenis interaksi yang beroperasi dalam sejarah konkret sastra lisan, yaitu: interaksi antara korpus tradisional yang berasal dari masa lalu dengan inovasi individu satu dengan individu lain, serta interaksi antara pertunjukan yang hidup dan aktual dari pelaku (Carrassi, 2017: 34).Peningkatan apresiasi atas sastra lisan melalui tindakan mereproduksi secara berulang maupun mendaur ulang dari satu generasi ke generasi lainnya membuka peluang munculnya kebosanan pada audiens (Khan, 2009: 144; Winona, Sinar, Sibarani, \& Takari, 2016: 56). Pada tradisi Nandung ini dimunculkan perubahan-perubahan yang akan menjadi pencegah terjadinya kebosanan pada audiens tersebut. Perubahan dari bentuk aslinya adalah adanya penambahan alat musik Ghebane yang mengiringi sastra lisan nandung ini. Oleh karena itu, penelitian ini akan membahas bentuk dari pertunjukan kesenian sastra lisan Nandung.

Marinis (Masayu, 2017: 70) mengungkapkan konsep pertunjukan yaitu pemain, busana, musik, tempat pentas dan penonton. Pertunjukan merupakan suatu kegiatan yang ditontonkan/ ditampilkan. Lebih lanjut lagi, Alviani (2012:38) menjelaskan sebuah pertunjukan musik mempunyai beberapa unsur antara lain tata panggung, pemain, penonton, materi penyajian, tata suara, tata lampu, tata rias, tata busana, dan alat musik.

Penanaman nilai yang terdapat dalam kesenian Nandung ini terdapat dari syairnya. Suyanto (Widodo, 2010) mengungkapkan sembilan pilar karakter yang berasal dari nilai-nilai luhur universal, yaitu: 1) karakter cinta Tuhan dan segenap ciptaanNya; 2) kemandirian dan tanggung jawab; 3) kejujuran/amanah, diplomatis; 4) hormat dan santun; 5) dermawan, suka tolong menolong dan gotong royong; 6) percaya diri dan pekerja keras; 7) kepemimpinan dan keadilan; 8) baik dan rendah hati; dan 9) karakter toleransi, kedamaian, dan kesatuan. Nilai-nilai yang terkandung dalam suatu karya seni bisa berupa nilai religius, moral dan pendidikan.

Rosmiati (2014:75) mengungkapkan teknik stimulasi dalam mendidik karakter pada anak-anak bisa melalui musik, nyanyian, suara, gerakan, bicara, perabaan, membaca, mencocokkan, membandingkan, mengelompokkan, memecahkan masalah, mencoret, merangkai, maupun menggambar. Dalam kesenian Nandung, nilai-nilai pendidikan, religius, dan moral ditanamkan melalui syairnya. Hal ini dilakukan dalam kapasitas manusia sebagai khalifah dan hamba Tuhan (Udu, Kusuma, Suarka, \& Alifuddin, 2017: 32). Terdapat karakteristik prinsip dari tiap individu yang terletak pada kapasitasnya untuk mentransformasi pemikirannya (Dąbrowska, 2010: 328).

Raditya (Tyasrinestu, 2014: 164) mengungkapkan dalam artikelnya bahwa eksistensi dari lagu hendaknya mempunyai fungsi dan guna dalam masyarakat dan musik sebagai media dalam menyampaikan pesan-pesan dalam liriknya. Keindahan lirik lagu menjadi salah satu faktor yang memengaruhi lagu tersebut dinyanyikan. Dalam sastra lisan Nandung, lirik menjadi media penyampaian pesan dan diiringi dengan musik dalam pertunjukannya.

Berdasarkan latar belakang yang telah dipaparkan di depan, maka peneliti tertarik meneliti bentuk pertunjukan sastra lisan Nandung, kemudian mengkaji nilai-nilai yang terkandung di dalam syairnya. Pertanyaan yang diajukan dalam penelitian ini adalah: 1) bagaimana bentuk pertunjukan sastra lisan nandung di Kota Rengat Kabupaten Indragiri Hulu Provinsi Riau?; dan 2) nilai-nilai apa sajakah yang terdapat dalam sastra lisan nandung di Kota Rengat Kabupaten Indragiri Hulu Provinsi Riau?

\section{Sejarah Perkembangan Nandung}

Pada awalnya, Nandung hanya berupa nyanyian atau lantunan kalimat La Ilaha Illalah dan ditambahkan dengan kalimat-kalimat yang mampu membuat anak tidur dalam buaian. Perkembangan Nandung menjadi lebih kompleks dengan ditambahkannya pantun yang berisikan tentang agama, nasehat, akhlak dan pengajaran pendidikan. Seiring waktu berlalu, masyarakat mulai menambahkan cara melantunkan nandung sama dengan irama saat membacakan ayat suci Al-Qur'an, sehingga pembacaan syair nandung ini memiliki ciri khas dan terus diwariskan secara 
turun temurun di dalam keluarga masyarakat daerah Kota Rengat dan sekitarnya.

Syair nandung yang dibacakan oleh seseorang yang paham seni membaca $A l-Q u r^{\prime}$ 'an, akan terasa berbeda dengan orang pada umumnya, karena irama yang dilantunkan akan memiliki perbedaan dari segi durasi, pola ritme dan melodi syairnya. Begitu pula dengan syairnya, tergantung dari kemahiran si penutur (ibu) dalam merangkai katakata berbentuk pantun untuk dilantunkan.

Saat ini Nandung telah mengalami perubahan bentuk penyajiannya. Biasanya Nandung hanya ada di dalam keluarga, khususnya dilakukan oleh ibu yang akan menidurkan anaknya. Saat ini, Nandung juga dapat ditemukan dalam sebuah pertunjukan. Menjadikan Nandung sebagai sebuah seni pertunjukan, merupakan upaya pelestarian dari kesenian sastra lisan.

\section{Bentuk Pertunjukan Nandung}

Dari hasil pengamatan di lapangan dan pengolahan data, dapat dijelaskan bahwa unsur dari pertunjukan Nandung ini yaitu:

\section{Penutur Sastra Lisan Landung}

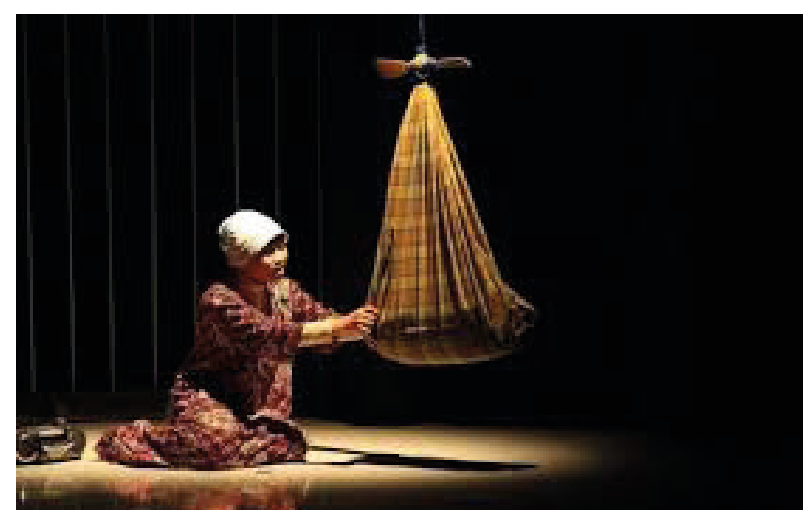

Gambar 1. Ibu Menidurkan Anaknya (beritajabtim.com)

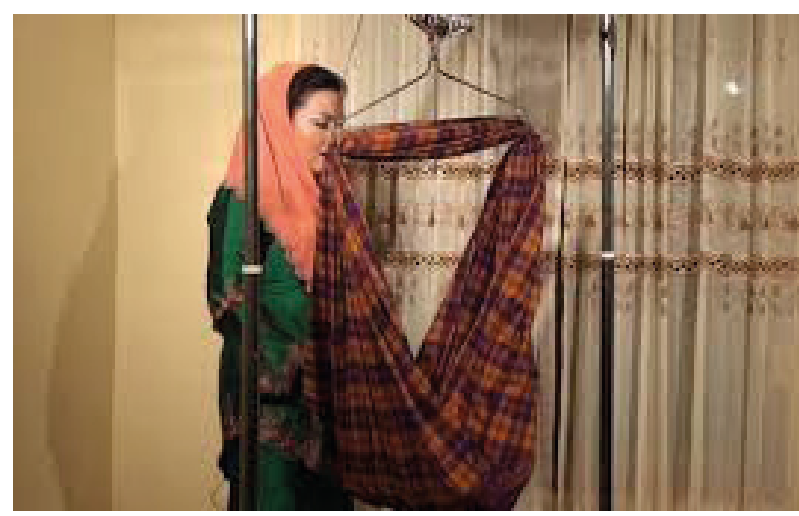

Gambar 2. Penutur Sastra Lisan Nandung (youtube.com)
Dalam aktivitas sehari-hari, sastra lisan nandung dituturkan oleh ibu-ibu yang menidurkan anaknya. Aktivitas ini merupakan bentuk nyata dari pentingnya peran orang tua dalam mendidik anaknya. Jadi, dalam format pertunjukannya pun sastra lisan nandung tetap dituturkan oleh ibu-ibu. Peran ibu yang menuturkan syair nandung ini adalah sebagai pendidik, khususnya mengajarkan pendidikan agama dan moral kepada anaknya sejak usia dini.

\section{Musik Sastra Lisan Nandung}

Dalam bentuk asli, sastra lisan Nandung tidak memiliki musik pengiringnya. Saat dilantunkan di rumah untuk menidurkan anak, sastra lisan Nandung hanya dituturkan oleh ibu saja sedangkan dalam bentuk pertunjukan, penampilan dari sastra lisan Nandung menggunakan alat musik yaitu Ghebane yang juga dimainkan oleh ibu-ibu. Penambahan alat musik pengiring menjadikan pertunjukan sastra lisan nandung menjadi lebih menarik.

\section{Tempat Pentas/Panggung}

Pentas dapat diartikan sebagai bagian dari panggung tempat melakukan pertunjukan. Panggung ini ditata sedemikian rupa, dengan

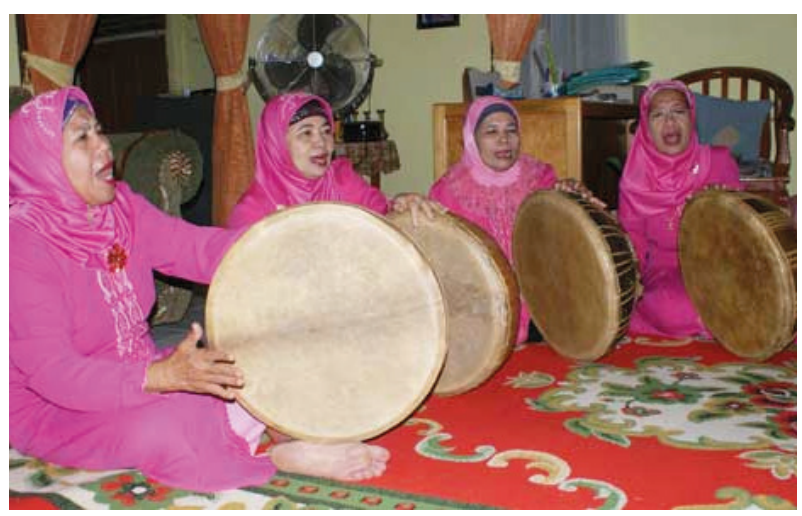

Gambar 3. Alat Musik Ghebane (riaupos.com)

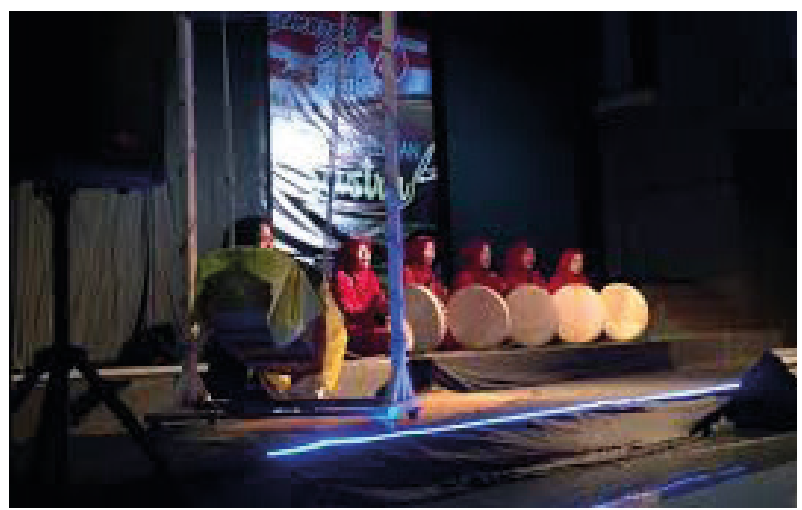

Gambar 4. Panggung Pertunjukan Nandung (youtube.com) 
pencahayaan yang diatur, sistem pengeras suara dan dekorasi panggung lainnya. Dalam pertunjukan sastra lisan nandung, panggung yang digunakan tidak berbeda dari panggungpanggung pada umumnya.

\section{Kostum}

Kostum yang digunakan oleh ibu yang menuturkan Nandung dalam bentuk pertunjukan berbeda dengan kostum yang digunakan oleh ibu-ibu di rumah, seperti baju kaos, dan daster. Penggunaan kostum dalam pertunjukan sastra lisan Nandung disesuaikan, tanpa adanya kostum yang baku, yang diutamakan adalah pakaian yang sopan dan rapi, serta menarik untuk dilihat penonton (Gambar 2).

\section{Penonton}

Penonton dalam konteks pertunjukan dapat diartikan sebagai orang yang hanya melihat pertunjukan, tanpa ikut campur dan bekerja untuk pertunjukan tersebut. Dalam aktivitas sehari-hari, saat ibu melantunkan Nandung untuk anaknya, yang melihat adalah keluarga di rumah tersebut. Sedangkan dalam bentuk pertunjukan yang dipentaskan, penonton sastra lisan nandung ini terdiri dari berbagai rentang usia, dari anak-anak hingga dewasa. Pentingnya melihat pertunjukan sastra lisan Nandung ini adalah terdapatnya pengajaran-pengajaran tentang agama dan ajaran baik lainnya.

\section{Syair Sastra Lisan Landung}

Syair yang terdapat dalam sastra lisan Nandung tidak ada yang baku, artinya syair yang disampaikan merupakan karangan sendiri maupun dari karangan-karangan sebelumnya. Kosa kata yang dikuasai oleh tiap penutur sastra lisan ini pasti tidak sama, oleh karena itu syairnya juga tidak ada yang baku. Berikut adalah contoh syair sastra lisan nandung oleh Ahmad Darmawi.

\section{La Ilaha Illallah}

Muhammad Rasulullah

Pualam diasah licinnya meningkat

Susun bertembung-nak sayang-uratnya merah
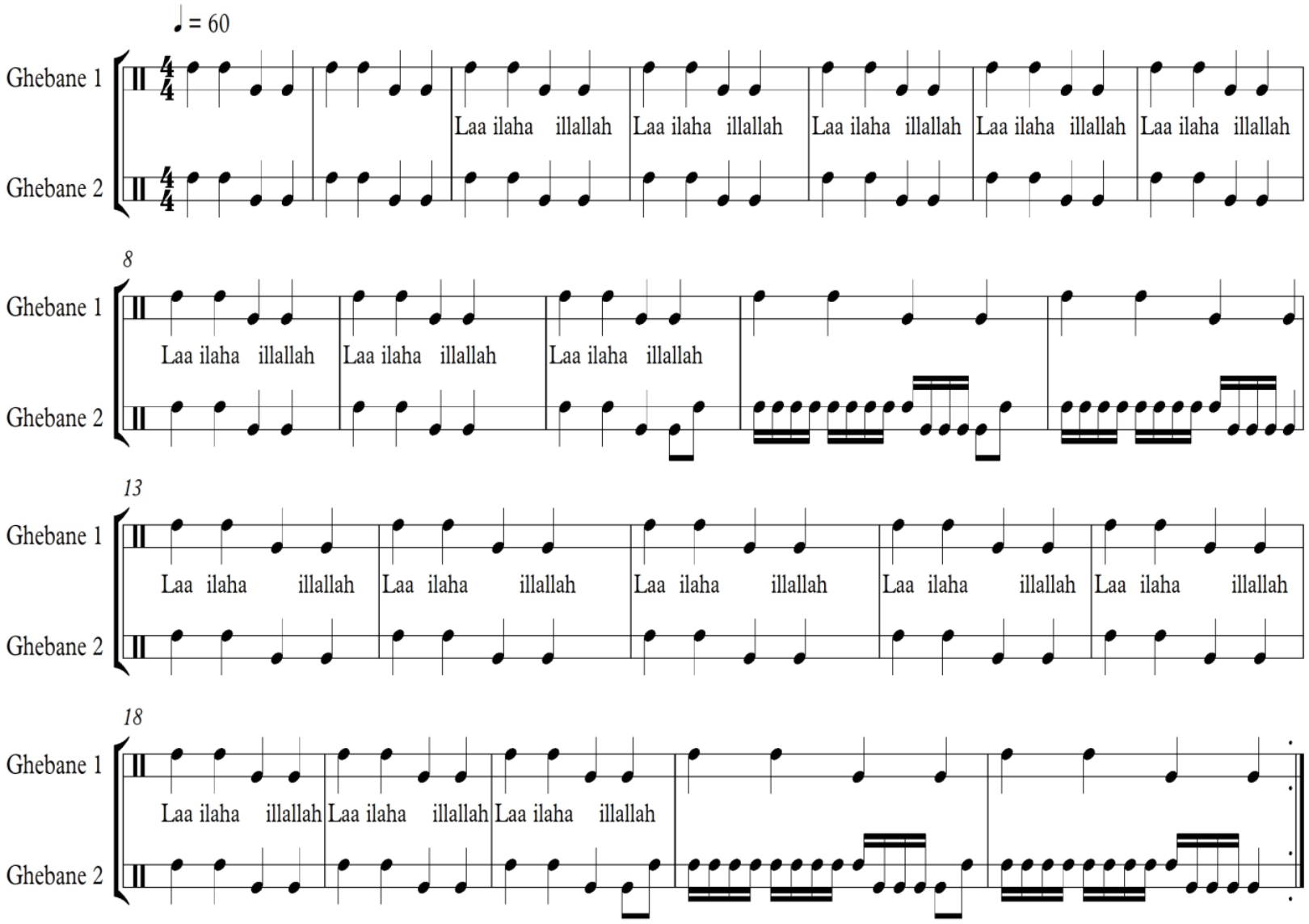

[line atas: Pak (high), line bawah: Dum (low)]

Notasi 1. Pola Ghebane dalam Kesenian Nandung (Sumber: Rofiandi, 2017) 


\section{Dengan Bismillah membuka kalimat}

Semoga nandung-nak sayang-membawa berkah

Rebung bambu iris iriskan

Perablah santan-nak sayang-tanak berkuah

Dudu si dudu bunda nandungkan

Dengarlah intan-nak sayang-nandung petuah Indah nian bunga di taman

Teman dilingkung-nak sayang-kawat berduri

Selama ananda dalam kandungan

Sakit dan perib-nak sayang-bunda alami

Dalam kehidupan sehari-hari, lirik yang disampaikan bisa saja berbeda, tergantung dari si penutur (ibu) yang akan menidurkan anaknya. Lirik syair nandung yang tidak baku ini, dikarenakan tiap-tiap ibu memiliki kemahiran yang berbeda untuk merangkai kata, panjang pendek lantunannya, serta isi yang ingin disampaikannya. Dalam satu wawasan seni verbal, akan terurai esensi idiomatik penutur, yang diorganisir logika narasi metonimi menjadi sistem makna budaya yang lebih besar (Thérèse de Vet, 2008: 160; Zemke, 2017: 226; Tarkka, 2017: 206). Syair Nandung ini tidak akan terlepas dari ajaran agama, akhlak, kasih sayang orang tua, dan nasehat.

\section{Bahasa Sastra Lisan Landung}

Bahasa yang digunakan dalam penuturan syair Nandung adalah bahasa Indonesia pada umumnya yang mudah dimengerti dan dipahami dengan dialek khas masyarakat melayu di Kota Rengat dan sekitarnya, seperti Kampung Pulau, Kampung Besar Seberang, dan Rantau Mapesai. Bahasa Melayu digunakan karena bahasa ini merupakan bahasa yang umum digunakan di Kota Rengat dan bahasa ini mampu menjadi ciri khas tersendiri dari sastra lisan Nandung yang terus bertahan dan berkembang hingga saat ini.

Tiap tiap bagian syair disampaikan dengan lantunan yang sama. Pembacaan syair Nandung dilafalkan dengan dialek bahasa melayu Kota Rengat, yang pada umumnya huruf "a” pada akhir kalimat dibaca "e". Walau demikian, tidak semua "a" dibaca "e". Berikut contoh syair yang pada lirik pertama dan ketiga, terdapat dua kata yaitu kebaya dan tua. Dalam pembacaan syair nandung, kata kebaya dibaca menjadi kebaye, kata tua dibaca menjadi tue.

\section{Kesumba lurik warna kebaya \\ Dipakai dara seri biduan \\ Berbuat baik pada orang tua \\ Akhlak utama setiap insan}

\section{Nilai Religius, Moral, dan Pendidikan dalam Sastra Lisan Landung}

\section{Nilai Religius}

Religius dapat diartikan sesuatu yang bersifat atau berkenaan dengan keagamaan. Nilai religius yang terdapat dalam sastra lisan Nandung, terlihat dari beberapa kutipan syair berikut.

Dari kecil cencilak padi

Sesudah besar cencilak padang

Dari kecil duduk mengaji

Sesudah besar tegak sembahyang

Syair di atas menunjukkan bahwa pengajaran agama Islam sangat dianjurkan oleh orang tua kepada anaknya, yaitu pentingnya belajar mengaji dan rajin sembahyang. Demikian juga syair berikut:

Di bulan Ramadhan orang puasa

Menahan selera mengekang nafsu

Orang beriman hidup sentosa

Kepada Allah tempat bertumpu

Pentingnya berserah diri kepada Allah merupakan pesan yang disampaikan oleh ibu kepada anaknya. Pada bulan Ramadhan, seorang anak harus berpuasa, dan yang terpenting harus beriman. Nilai religius juga terdapat pada syair berikut.

\section{Jauh berjalan banyak dilihat}

Lama hidup-nak sayang-banyak dirasa

Bila badan banyak ibadat

Niscaya engkau-nak sayang-banyak pahala

Sempurna helat karena beradat

Terpelihara harkat-nak syang-terpelihara marwah

Sempurnakan syariat menuju hakikat

Niscaya makrifat-nak sayang-kepada Allah

Penanaman nilai religius oleh orang tua kepada anaknya melalui sastra lisan Nandung merupakan bukti nyata tentang pentingnya pengajaran agama pada anak sejak usia dini. Pendidikan yang berlandaskan agama diharapkan mampu membentuk karakter dan perilaku anak. 


\section{Nilai Moral}

Moral diartikan sebagai perilaku baik buruk yang berkaitan dengan etika dan sopan santun. Nilai moral yang terdapat dalam sastra lisan Nandung, terlihat dari beberapa kutipan syair berikut.

Kesumba lurik warna kebaya

Dipakai dara seri biduan

Berbuat baik pada orang tua

Akblak utama setiap insan

Pengajaran tentang moral yaitu sopan santun dan taat kepada orang tua merupakan salah satu nilai yang terdapat dalam sastra lisan Nandung. Kutipan syair berikut juga mengajarkan nilai nilai moral.

Sikurik kundi simerah saga

Bersulam tekat ranggi tenunan

Baikkan budi pada sesama

Kaum kerabat mesti diutamakan

Pentingnya selalu berbuat baik pada sesama, juga merupakan salah satu ajaran yang diberikan oleh orang tua kepada anaknya. Dengan selalu berbuat baik, maka kehidupan akan menjadi tenang dan damai.

\section{Nilai Pendidikan}

Pendidikan dapat diartikan sebagai pengajaran untuk mengubah sikap dan menambah ilmu pengetahuan. Nilai pendidikan yang terdapat dalam sastra lisan Nandung terlihat dari beberapa kutipan syair berikut.

Kasih ayah sepanjang jalan

Kasih bunda-nak sayang-sepanjang hayat

Jika ilmu engkau peliharakan

Niscaya bahagia-nak sayang-dunia akhirat

Pentingnya pendidikan bagi anak, diajarkan oleh orang tua melalui syair dalam sastra lisan Nandung. Ilmu yang berguna dan bermanfaat bagi orang lain, tentu akan membuat diri selalu bahagia, baik di dunia maupun di akhirat. Nilai pendidikan juga terdapat pada syair berikut.

Rebung bambu iris-iriskan

Perahlah santan-nak sayang-tanak berkuah

Dudu si dudu bunda nandungkan

Dengarlah intan-nak sayang-nandung petuah

Nandung petuah adalah Nandung yang berisikan pendidikan untuk anak, di antaranya mendidik tentang ilmu agama, ajaran kebaikan dan kehidupan sosial. Peran orang tua sangat diperlukan dalam pendidikan anak, khususnya dimulai sejak usia dini. Sastra lisan Nandung adalah salah satu bukti nyata pentingnya peran orang tua mendidik anak sejak usia dini, yang dimulai dari pendidikan informal (keluarga).

\section{Penutup}

Nandung adalah sastra lisan yang digunakan untuk menidurkan anak yang disampaikan dengan syair yang berbentuk pantun. Nandung juga memiliki arti yang sama dengan kata nyanyian, yaitu melantunkan lirik-lirik (pantun) dengan cara dinyanyikan dengan menggunakan irama yang khas untuk menidurkan anak.Nandung berisikan syair tentang agama, nasehat, akhlak, tunjuk ajar, dan pengajaran pendidikan.

Berdasarkan perkembangannya, sastra lisan nandung saat ini mulai ditampilkan dalam bentuk pertunjukan dengan penambahan alat musik yaitu Ghebane. Dalam kaitannya dengan bentuk pertunjukan, sastra lisan nandung dapat dilihat dari penuturnya, musik pengiring, panggung, kostum, penonton, syair dan bahasa yang digunakan. Dilihat dari nilai-nilai yang tertanam di dalam syairnya, terdapat nilai religius, nilai moral dan nilai pendidikan.

\section{Kepustakaan}

Alviani, Euis Septia. (2012). Bentuk Pertunjukan Orkes Dangdut Parodi Senggol Tromol di Semarang: Kajian Bentuk dan Fungsi. Harmonia: Journal of Arts Research and Education, 12(1), 32-43.

Carrassi, V. (2017). Between Folk and Lore. Performing, Textualising and (mis) Interpreting the Irish Oral Tradition, (12), 32-46.

Dąbrowska, K. M. (2010). " Secret Language " in Oral and Graphic Form: ReligiousMagic Discourse in Aztec Speeches and Manuscripts. Language, 2, 325-363. https:// doi.org/10.1353/ort.2010.0026

Darmawi, Ahmad. (2006). Sastra Lisan Nandung 
Indragiri Hulu. Pekanbaru: Dinas Kebudayaan Kesenian dan Pariwisata Provinsi Riau.

Karim, Maizar. (2015). Menyelisik Sastra Melayu. Yogyakarta: Histokultura.

Khan, A. W. (2009). Paradigms of Social Aesthetics in Themne Oral Performance. Oral Tradition, 24(1), 143-159. https://doi.org/10.1353/ ort.0.0039

Rahman, Elmustian, et al. (2010). Riau Tanah Air Kebudayaan Melayu Wisdom 2010 "Local Wisdom Inspiring Global Solutions”. Pekanbaru: Tim Muhibah Seni Budaya Melayu Riau: Melayu Sejati.

Rhoads, D. (2010). Biblical Performance Criticism: Performance as Research. Part of a Special Issue: Oral Tradition in Judaism, Christianity, and Islam, 25(1), 157-197.

Rosmiati, Ana. (2014). Teknik Stimulasi dalam Pendidikan Karakter Anak Usia Dini melalui Lirik Lagu Dolanan. Resital Jurnal Seni Pertunjukan, 15(1), 71-82.

Sabillah, Selly Masayu. (2017). Adaptabilitas Seniman Pertunjukan Sastra Tutur Tadut Sebagai Kearifan Lokal Dalam Menghadapi Perubahan Sosial Kehidupan Masyarakat Basemah Pagaralam. [Tesis]. Semarang: Pascasarjana Pendidikan Seni. Universitas Negeri Semarang.

Sibarani, R. (2015). Pendekatan Antropolinguistik terhadap Kajian Tradisi Lisan. Retorika: Jurnal Ilmu Bahasa, 1(1), 94-107. https://doi. org/10.22225/jr.1.1.105.1-17

Syarifudin. (2009). Adaptasi Linguistik Bahasa Luar terhadap Tradisi Lisan (Mantra) Masyarakat Bajo: Sebuah Transformasi Budaya. Linguistik dan Sastra, 21(1), 81-90

Tarkka, L. (2017). Parallelism in Verbal Art and Performance: An Introduction. Oral Tradition, 2(1), 203-232.

Thérèse de Vet. (2008). Context and the Emerging Story: Improvised Performance in Oral and Literate Societies. Oral Tradition, 23, 159179. https://doi.org/10.1353/ort.0.0020

Tyasrinestu, F. (2014). Lirik Musikal Pada Lagu Anak Berbahasa Indonesia. Resital Jurnal Seni Pertunjukan, 15(2), 163-168

Udu, H., Kusuma, I. N. W., Suarka, I. N., \& Alifuddin, M. (2017). Kangkilo Oral Tradition: Reflection of Sufism and Political Powers in Buton Community. E-Journal of Linguistics, 11(1), 30-53.

Winona, T., Sinar, T. S., Sibarani, R., \& Takari, M. (2017). The Performance, Text,and Context Cenggok-Cenggok Malay Panai LabuhanbatuSumatera Utara, Indonesia. JAH, 6(7), 55-61. Widodo. (2010). Lelagon Dolanan Anak dan Pendidikan Karakter. Harmonia: Journal of Arts Research and Education, 10(2)

Zemke, J. (2017). Units of Measurement: Oral Tradition, Translation Studies And Corpus Linguistics. SEFAD, 2017(37), 225-238.

\section{Informan}

Mailiswin (59 tahun). Budayawan dan Ketua Dewan Kesenian Kabupaten Indragiri Hulu. 